\title{
Entry and dispersion of microorganisms inside Altamira Cave. New evidences from aerobiological and atmospheric gases surveys
}

\author{
E. Garcia Anton, A. Fernandez-Cortes, M. Alvarez-Gallego \& S. Sanchez-Moral \\ Museo Nacional de Ciencias Naturales, CSIC, Madrid, Spain \\ S. Cuezva \\ Universidad de Alicante, Alicante, Spain \\ E. Sanz-Rubio \\ Geomnia Natural Resources SLNE, Madrid, Spain
}

V. Jurado, E. Porca \& C. Saiz-Jimenez

Instituto de Recursos Naturales y Agrobiologia, CSIC, Sevilla, Spain

\begin{abstract}
Altamira Cave, a UNESCO World Heritage Site, houses one of the world's most prominent Palaeolithic rock art. The conservation of the rock art is threatened by microorganisms (bacteria and recently fungi). Previous studies revealed that the entry and dispersion of microorganisms and nutrients to the interior of the cave depends on the exchange rates between the cave atmosphere and the exterior through the entrance. Nevertheless, the data obtained in an aerobiological study combined with a multiparametric survey of atmospheric gases have shown that there is another possible entry and spread of microorganisms in the innermost area of the cave (the Well Hall), far from the single and most elevated entrance.
\end{abstract}

\section{INTRODUCTION}

Altamira (Cantabria, northern Spain) is a well-studied cave that houses one of the world's most prominent Palaeolithic rock art (Saiz-Jimenez et al. 2011). The cavity (270 $\mathrm{m}$ in length) is situated on a topographical hill (152 m a.s.l.) and has a depth of 3-22 $\mathrm{m}$ (average $8 \mathrm{~m}$ ) below the surface. The cavity has a single entrance in topographically higher position, and includes a number of main halls having a downward trend from the outside access to the deepest part of the cave (Fig. 1). At present, the cave is permanently closed to visitors. The main entrance is closed by a metal gate (slotted surface $<4 \%$; thermally insulated) acting as the initial barrier to stop the exchange of matter with the outside. In addition a second door isolates the Kitchen Hall of the Crossing and the rest of the cavity (mainly the Polychrome Hall and Walls Hall).

Previous studies revealed that entry and dispersion of microbes (and nutrients) to the interior of the Altamira Cave depends on the exchange rates between the cave atmosphere and the exterior through the entrance (Cuezva et al. 2009, Saiz-Jimenez et al. 2011). These exchange rates are higher during the summer season (Cuezva et al. 2011). However, knowledge of other possible entries of microorganisms (and nutrients) is essential in order to ensure the conservation of rock art.

Here, we use a double analytical approach. First, a multiparametric survey of atmospheric gases developed for determining the spatial distribution of carrier $\left(\mathrm{CO}_{2}\right)$ and trace $\left(\mathrm{CH}_{4}\right)$ gases and the isotopic signal of $\mathrm{CO}_{2}\left(\delta^{13} \mathrm{C}\right)$. Secondly, an aerobiological study conducted to quantify the concentration and diversity of airborne microorganisms and their spatial distribution.

\section{MATERIAL AND METHODS}

Cave air conditions are influenced by interaction processes with the outer atmosphere. In order to characterize cave levels of $\mathrm{CO}_{2}, \delta^{13} \mathrm{CO}_{2}$ and $\mathrm{CH}_{4}$ certain number of air samples were taken along the cave covering the whole inner space in July 2012 (Fig. 1). 


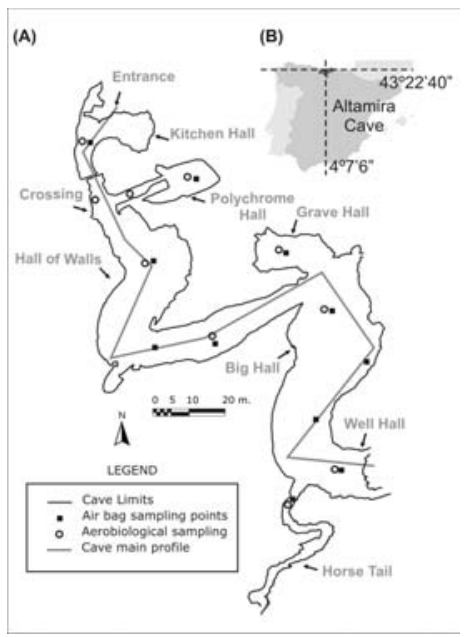

Figure 1. (A) Altamira Cave map with location of the aerobiological and atmospheric gases sampling points inside the cavity. (B) Geographic location of the cave.

Samples were obtained by filling Tedlar air sampling bags with capacity of $1 \mathrm{~L}$. Air is introduced inside the bag by using a hand air pump. Special seal system ensures the sample during transport and temporal storage. Samples were analyzed afterwards in laboratory by using an optic spectrometer Picarro G2101-i. The device identifies and quantifies different compounds in the optical spectrum obtained. Isotopic relationship $\delta^{13} \mathrm{CO}_{2}$ is measured as a calculation from ${ }^{12} \mathrm{CO}_{2}$ and ${ }^{13} \mathrm{CO}_{2}$ concentrations analyzed by the spectral system. Precisions of $200 \mathrm{ppb}, 10 \mathrm{ppb}$ and $0.3 \%$ are guaranteed for ${ }^{12} \mathrm{CO}_{2},{ }^{13} \mathrm{CO}_{2}$ and $\delta^{13} \mathrm{CO}_{2}$ respectively. Precision of $0.1 \mathrm{ppm}$ has been obtained for $\mathrm{CH}_{4}$ compound in the concentration range studied (0-2 ppm).

An extensive aerobiological sampling all over the cave was conducted in June 2009 to quantify the level of airborne bacteria and fungi. The methodology used was published elsewhere (Fernandez-Cortes et al. 2011).

\section{RESULTS AND DISCUSSION}

A cave environment is characterized by high levels of $\mathrm{CO}_{2}$ with very low $\delta^{13} \mathrm{C}$ isotopic signal values and low levels of $\mathrm{CH}_{4}$ compared with the external atmosphere. Average values recorded in Altamira Cave and its surroundings in the samplings carried out in July 2012 are shown in Table 1.

Table1. Environmental parameters in Altamira Cave

\begin{tabular}{|c|c|c|c|}
\hline Air & $\mathrm{CO}_{2}(\mathrm{ppm})$ & $\delta^{13} \mathrm{C}\left(\mathrm{CO}_{2}\right) \%$ & $\mathrm{CH}_{4}(\mathrm{ppm})$ \\
\hline Cave & 1257 & -19.9 & 0.62 \\
\hline Top soil & 2887 & -20.5 & 1.38 \\
\hline Exterior & 420 & -8.5 & 1.70 \\
\hline
\end{tabular}

Data analysis using Keeling's Plot (Keeling 1958) indicated that the $\mathrm{CO}_{2}$ present in the ecosystem has a soil-derived origin. Figure 2 shows that inside the cave the lowest $\mathrm{CO}_{2}$ concentration correspond to the Entrance Hall due to the connection with the external atmosphere. This external influence is progressively reduced from the entrance inwards reaching the lower isotope signal values, maximum $\mathrm{CO}_{2}$ and minimum $\mathrm{CH}_{4}$ concentrations in the innermost areas (between the Great Hall and the Well Hall). However, in the last hall (Well Hall) is noticed a change of trend despite being the farthest hall from the only known accessible entrance. The slight increase of $\mathrm{CH}_{4}$ and a lower concentration of $\mathrm{CO}_{2}$ with heavier isotope values indicate the presence of an unknown connecting track to the outside near or in the Well Hall area. 
Regarding the level of airborne microorganisms (bacteria and fungi), a distinct behavior along the cave has been observed. The concentration of fungal spores outdoor the cave is higher than inside the cave. Throughout the cave, the concentration of fungal spores is higher in the halls and galleries close to the entrance (Kitchen Hall, Crossing, Polychrome Hall) and is reduced towards the interior (Walls Hall). The concentration of fungal spores reaches its minimum in the Grave Hall and Great Hall, ranging between 10 and 21 colony forming units $(\mathrm{CFU}) / \mathrm{m}^{3}$. However, the Well Hall reached $50 \mathrm{CFU} / \mathrm{m}^{3}$. This can be attributed to a direct connection of the Well Hall with the exterior. Interestingly, a major abundance of Cladosporium spores was observed in Altamira, which is not common in other caves studied (FernandezCortes et al. 2011, Porca et al. 2011). In the halls near the entrance, considering Walls Hall, Crossing, and Polychrome Hall all together, Cladosporium attained 79.6\%, followed by Epicoccum (18.0\%), Penicillium (1.0\%), and Aspergillus (0.5\%). Because Cladosporium and Epicoccum are considered common outdoor fungi, it is suggested that the abundance of Cladosporium all over the cave can be a consequence of the existence of a connection with the exterior not only at the entrance but also at the end of the cave, in the Well Hall. In fact, $84 \%$ of the fungal spores present in the Well Hall belong to Cladosporium.

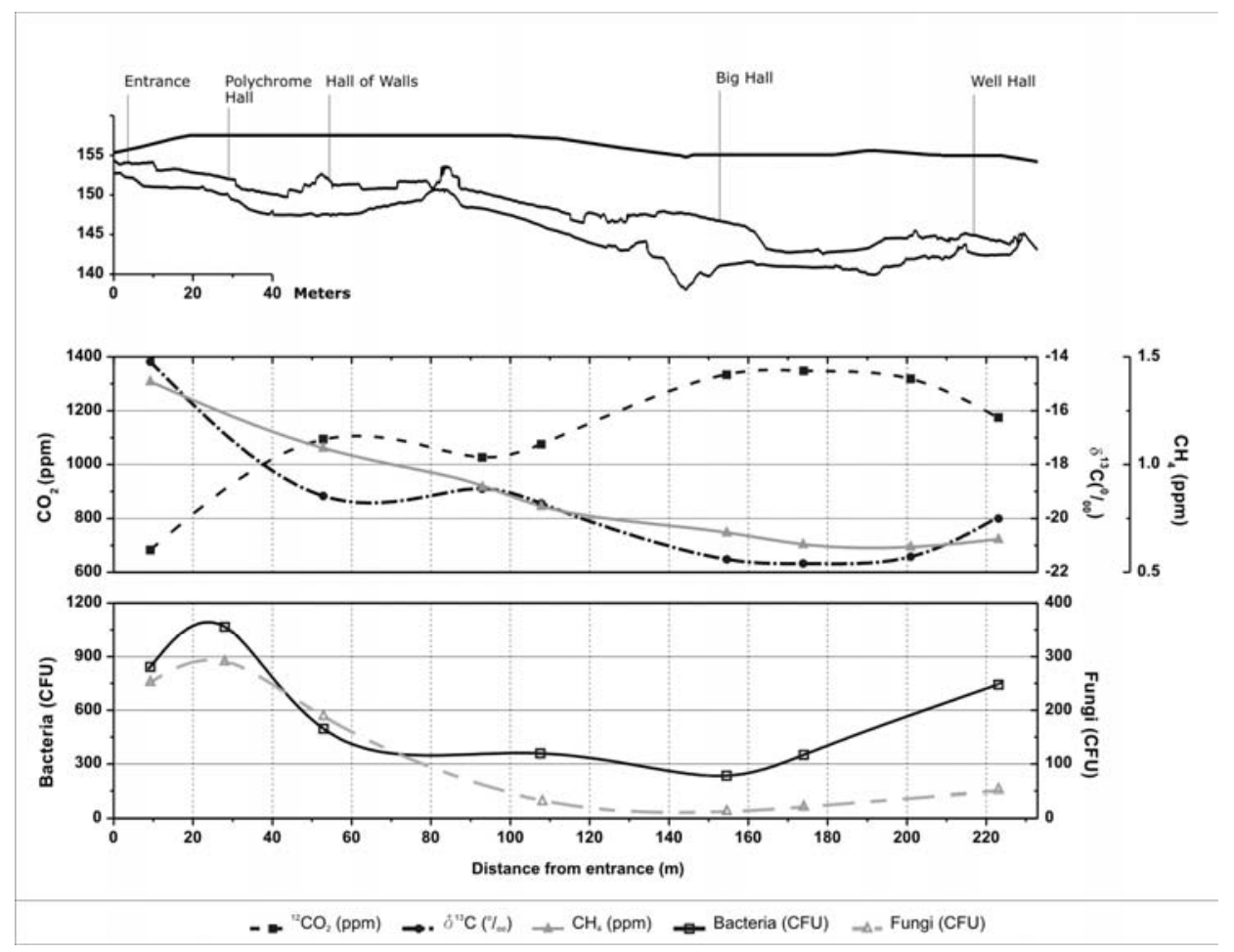

Figure 2. In profile, spatial distribution of airborne bacteria and fungal spores in Altamira Cave (June 2009) and $\mathrm{CO}_{2}, \delta^{13} \mathrm{CO}_{2}$ and $\mathrm{CH}_{4}$ (July 2012) in the air of Altamira Cave.

The airborne concentration of bacteria inside the cave is higher than that recorded outside and also much higher than of the fungi. This can be understood taking into account that the ceiling and walls of Altamira Cave (Kitchen Hall, Crossing, Polychrome Hall and Walls Hall) are widely colonized by bacteria (Cuezva et al. 2009, Saiz-Jimenez et al. 2011). Thereby, the higher concentrations of airborne bacteria were found in the Crossing and entrance to Polychrome Hall. Considering all samplings together, the most abundant bacteria in Altamira Cave air was Micrococcus luteus (83.2\%), followed by different species of Pseudomonas (7.8\%) and Bacillus (2.1\%). In the halls near the entrance (Walls Hall, Crossing, and Polychrome Hall), M. luteus concentrations ranged between 77.3 and $88.9 \%$, while in some other halls (Wells Hall, Grave Hall) was absent.

Again the influence of a possible connection exterior-interior in the Well Hall is confirmed by the increasing number of bacteria in this hall $\left(740 \mathrm{CFU} / \mathrm{m}^{3}\right.$, from which $89.2 \%$ belonged to Bacillus weihenstephanensis, a soil-dwelling bacterium) in comparison with the samplings ob- 
tained in the nearby halls (Great Hall: $360 \mathrm{CFU} / \mathrm{m}^{3}$ and Horse Tail Gallery: $280 \mathrm{CFU} / \mathrm{m}^{3}$ ). The Grave Hall that is an inferior hall, isolated in some way from the rest of the cave, shows the lower bacteria concentration in the cave $\left(150 \mathrm{CFU} / \mathrm{m}^{3}\right)$.

The caves are considered oligotrophic environments, and areas with direct communication with the outside favor the entry of microorganisms and the development and dissemination of microbial colonizations. In Altamira Cave the area near the entrance has a higher level of airborne microorganisms in relation to nearby halls. However, an anomaly in the Well Hall in relation to nearby halls reveals a connection with the outer atmosphere at this site.

\section{CONCLUSIONS}

Gaseous phase exchange processes are the main natural factor for the entry and dispersion of microorganisms into Altamira Cave. Thus the main problem is the opening of the door, which reinforces the role of the atmosphere as a vehicle for the transport and dispersion of airborne microorganisms and nutrients inside the cave. The data obtained have shown that there is another possible entry of microorganisms in the innermost area of the cave (the Well Hall), far from the single and most elevated entrance. In fact, in the Well Hall the high level of airborne microorganisms in relation to nearby halls and galleries reveals a connection with the outer atmosphere at this site, which is also supported by the spatial distribution of carrier $\left(\mathrm{CO}_{2}\right)$ and trace $\left(\mathrm{CH}_{4}\right)$ gases and isotopic signal of $\mathrm{CO}_{2}\left(\delta^{13} \mathrm{C}\right)$. The presence of other cavities in a topographically lower position than Altamira and with direct connection to the outside could be the origin of the observed anomaly. This fact reinforces the importance of the second door, which separates the Kitchen Hall from the Crossing to prevent air flows between the old entrance and the Well Hall external connection. The data reported should be taken into account in future cave managements and conservation measures.

\section{ACKNOWLEDGEMENTS}

This research was supported by the project CGL2010-17108 BTE. E.G-A. was supported by a CSIC JAE-Predoctoral grant. A.F-C benefits from the JAE-Doc Program, and S.C. from a Juan de la Cierva grant. Altamira Cave and Museum staff is acknowledged for their collaboration throughout the research period. This work was also funded by the Spanish Research Programme on Technologies for the Assessment and Conservation of Cultural Heritage (CSD2007-00058).

\section{REFERENCES}

Cuezva, S., Sanchez-Moral, S., Saiz-Jimenez, C. \& Cañaveras, J.C. 2009. Microbial communities and associated mineral fabrics in Altamira Cave, Spain. International Journal of Speleology 38: 83-92.

Cuezva, S., Fernandez-Cortes, A., Benavente, D., Serrano-Ortiz, P., Kowalski, A.S. \& Sanchez-Moral, S. 2011. Short-term $\mathrm{CO}_{2}(\mathrm{~g})$ exchange between a shallow karstic cavity and the external atmosphere during summer: Role of the surface soil layer. Atmospheric Environment 45: 1418-1427.

Fernandez-Cortes, A., Cuezva, S., Sanchez-Moral, S., Porca, E., Jurado, V. \& Saiz-Jimenez, C. 2011. Detection of human-induced environmental disturbances in a show cave. Environmental Science and Pollution Research 18: 1037-1045.

Keeling, C.D. 1958. The concentration and isotopic abundances of atmospheric carbon dioxide in rural areas. Geochimica et Cosmochimica Acta 13: 322-334.

Porca, E., Jurado, V., Martin-Sanchez, P.M., Hermosin, B., Bastian, F., Alabouvette, C. \& Saiz-Jimenez, C. 2011. Aerobiology: An ecological indicator for early detection and control of fungal outbreaks in caves. Ecological Indicators 11: 1594-1598.

Saiz-Jimenez, C., Cuezva, S., Jurado, V., Fernandez-Cortes, A., Porca, E., Benavente, D., Cañaveras, J.C. \& Sanchez-Moral, S. 2011. Paleolithic art in peril: policy and science collide at Altamira Cave. Science 334: 42-43. 